\title{
Effect of Relational Bonds on Consumer Engagement Via Affective Commitment on E-Commerce Live Stream Shopping in Indonesia
}

\author{
Dito Tunjung Parahyta ${ }^{1, *}$, Nurdin Sobari ${ }^{2}$ \\ ${ }^{1,2}$ University of Indonesia, Indonesia \\ ${ }^{*}$ Corresponding author. Email: dito.tunjung01@ui.ac.id
}

\begin{abstract}
Lately, Live streaming is one of the entertainment activities that can enhance consumers' shopping experience. As many as $29 \%$ of internet users often watch the live streaming from influencers on social media, and $80 \%$ of them tend to buy the products offered. Ranked first globally, $88.1 \%$ of internet users in Indonesia use e-commerce services, with e-commerce transaction volume reaching IDR 266 trillion in 2020. However, not much research has been done on live streaming shopping, especially on Indonesian e-commerce. Based on the stimulus-organismreaction framework, this study examines the effect of relational bonds on consumer engagement via affective commitment in live stream shopping e-commerce Indonesia. Using 266 valid online survey responses, researchers used AMOS software to evaluate measurement \& structural models. The study results found that social bonds indirectly affect consumer engagement through an affective commitment to broadcasters. Meanwhile, financial \& structural bonds only affect affective commitment to the platform but do not affect consumer engagement. This study provides insight for e-commerce operators in Indonesia to increase consumer engagement by developing social bonds in live streaming shopping.
\end{abstract}

Keywords: Live Stream Shopping, Financial Bonds, Social Bonds, Structural Bonds, Affective Commitment, Consumer Engagement, E-Commerce

\section{INTRODUCTION}

Live streaming has emerged as entertainment activities that can enhance consumer's shopping experience [1]. With more and more consumers shop online due to the COVID-19 pandemic, the shift from physical stores to digital stores globally has accelerated for about five years [2]. As many as $29 \%$ of internet users often watch live streaming from influencers on social media, and $80 \%$ of them tend to buy the products offered [1]. Thus, selling live streaming is one of the keys to staying relevant and prominent in the retail world, which increasingly prioritizes online interaction. Ranked first globally, as many as $88.1 \%$ of Indonesian internet users used ecommerce services to buy products [3]. Three of Indonesia's four major e-commerce platforms have implemented the live stream shopping feature to enhance consumers' shopping experience.
Studies done related to live streaming mainly focus on motivation and user experience for entertainment and knowledge sharing purposes [4] [5]. One study that examines streaming as a medium of buying and selling online (live stream shopping) is conducted by [6]. In the research, it was found empirically that relational bonds can affect consumer engagement via affective commitment. However, this research has only been carried out in one country and only on one platform, namely the Taobao platform in China. [6] suggest seeing if there are differences in the phenomenon of live stream shopping in e-commerce in countries with cultural differences. This study aims to investigate Indonesian e-commerce further to complement and fill the limitations of previous research, the effect of relational bonds on consumer engagement via affective commitment on live stream shopping on e-commerce platforms in Indonesia. 
Table 1. Assessment of Measurement Model

\begin{tabular}{|c|c|c|c|c|}
\hline Variable & Indicator & Factor Loading & $\begin{array}{l}\text { Composite } \\
\text { Reliability }\end{array}$ & $\begin{array}{l}\text { Average Variance } \\
\text { Extracted (AVE) }\end{array}$ \\
\hline \multirow[t]{3}{*}{ Financial Bonds (FB) } & FB-1 & .669 & .736 & .483 \\
\hline & FB-4 & .771 & & \\
\hline & FB-5 & .639 & & \\
\hline \multirow[t]{4}{*}{ Social bonds (SOB) } & SOB-1 & .791 & .801 & .503 \\
\hline & SOB-2 & .650 & & \\
\hline & SOB-3 & .755 & & \\
\hline & SOB-4 & .629 & & \\
\hline \multirow[t]{4}{*}{ Structural bonds (STB) } & STB-1 & .777 & .798 & .499 \\
\hline & STB-2 & .781 & & \\
\hline & STB-3 & .611 & & \\
\hline & STB-4 & .641 & & \\
\hline Affective commitment to & $\mathrm{AB}-1$ & .724 & .769 & .527 \\
\hline \multirow[t]{2}{*}{ Broadcaster (AB) } & AB-2 & .657 & & \\
\hline & $\mathrm{AB}-4$ & .791 & & \\
\hline Affective commitment to & AP-1 & .739 & .814 & .524 \\
\hline \multirow[t]{3}{*}{ Platform (AP) } & AP-2 & .657 & & \\
\hline & AP-3 & .767 & & \\
\hline & AP-4 & .727 & & \\
\hline \multirow{7}{*}{$\begin{array}{l}\text { Consumer engagement } \\
\text { (CE) }\end{array}$} & CE-1 & .866 & .907 & .584 \\
\hline & CE-2 & .804 & & \\
\hline & CE-3 & .786 & & \\
\hline & CE-4 & .722 & & \\
\hline & CE-5 & .737 & & \\
\hline & CE-6 & 649 & & \\
\hline & CE-7 & .766 & & \\
\hline
\end{tabular}

\section{LITERATURE REVIEW}

\subsection{E-commerce \& Live Stream Shopping}

Electronic commerce (e-commerce) is defined as the process of buying and selling products, information, and services, via computer networks [7]. Some of the characteristics of e-commerce are; consumer relations generally interact individually and independently, the interaction system is only one-way, has the business goal of maximizing shopping efficiency [8], [9].

Buying and selling activities and transactions using live streaming media can be called live streaming commerce [10], (live stream shopping). In general, live stream shopping activities are usually used to sell products by broadcasting videos in realtime to show different views of the product and encourage viewers to buy it [6], [11], [12]. By watching live stream shopping, consumers can get dynamic and accurate product information, develop social relationships with fellow consumers and broadcasters while entertaining themselves while watching interesting broadcasters [13].

\subsection{Stimulus-Organism-Response (SOR) model}

The SOR model was introduced by Mehrabian \& Russell [14] and later updated by Jacoby [15]. Stimuli can trigger a person's cognitive and emotional processes (organisms) and then lead to certain behaviors (responses) [16]. Many studies use SOR to explain consumer behavior in shopping contexts ranging from the retail, online shopping, website impulsive purchases, and intention to purchase in online retailing[17]-[20].

\subsubsection{Relational Bonds}

There are three types of relational bonds that are often the main focus in the literature: financial, social,nd structural bonds [6]. Financial bonds (FB) are closely related to financial incentives such as price discounts, promo prices, and loyalty points. Social bonds (SOB), focus on interpersonal interactions such as interacting with live streams and identifying loyal buyers [21]. Structural bonds (STB) provide services that can add value to the live stream, such as providing information that is difficult to obtain elsewhere. 


\subsubsection{Affective Commitment}

As a long-term desire to maintain a relationship, affective commitment plays an important role in building and developing a relationship [22]-[24]. There are several aspects involved in affective commitment in the context of retailing, namely brands, sellers, shop assistants (broadcasters) and online marketplaces (Platforms) [6]. This research focuses on two aspects, namely broadcasters $(\mathrm{AB})$ and platform (AP), because these two aspects directly affect the consumer experience when following live streaming [6].

\subsubsection{Consumer Engagement}

Streaming feature for online shopping (Live Streaming Shopping) on e-commerce platforms (Tokopedia, Shopee, Lazada, etc.). The sampling technique was purposive sampling. Measurement model analysis was performed using confirmatory factor analysis (CFA), and structural analysis (hypothesis analysis) using structural equation modeling (SEM) with AMOS software. The total valid samples obtained in this study were 276 consumers who had watched live stream shopping on Indonesian e-commerce platforms.

\subsection{Questionnaire \& Measures}

The data in this study were obtained by providing

Table 2. Path Analysis Result

\begin{tabular}{llrrrl}
\hline Hypotheses & Path & Coefficient & t-value & p-value & Result \\
\hline H1a & FB $\rightarrow \mathrm{AB}$ & .038 & 0.38 & .705 & Not supported \\
H1b & FB $\rightarrow$ AP & .236 & 2.47 & .013 & Supported \\
H2a & $\mathrm{SOB} \rightarrow \mathrm{AB}$ & .864 & 3.89 & $<.001$ & Supported \\
$\mathrm{H} 2 \mathrm{~b}$ & $\mathrm{SOB} \rightarrow \mathrm{AP}$ & -.253 & -0.98 & .327 & Not supported \\
$\mathrm{H} 3 \mathrm{a}$ & $\mathrm{STB} \rightarrow \mathrm{AB}$ & -.089 & -0.43 & .670 & Not supported \\
$\mathrm{H} 3 \mathrm{~b}$ & $\mathrm{STB} \rightarrow \mathrm{AP}$ & .451 & 2.26 & .024 & Supported \\
$\mathrm{H} 4$ & $\mathrm{FB} \rightarrow \mathrm{CE}$ & -.013 & -0.19 & .851 & Not supported \\
$\mathrm{H} 5$ & $\mathrm{SOB} \rightarrow \mathrm{CE}$ & .019 & 0.1 & .919 & Not supported \\
$\mathrm{H} 6$ & $\mathrm{STB} \rightarrow \mathrm{CE}$ & .119 & 0.79 & .432 & Not supported \\
$\mathrm{H} 7 \mathrm{a}$ & $\mathrm{AB} \rightarrow \mathrm{CE}$ & .724 & 4.98 & $<.001$ & Supported \\
$\mathrm{H} 7 \mathrm{~b}$ & $\mathrm{AP} \rightarrow \mathrm{CE}$ & .162 & 1.56 & .120 & Not supported \\
$\mathrm{H} 8$ & $\mathrm{AB} \rightarrow \mathrm{AP}$ & .518 & 3.5 & $<.001$ & Supported \\
\hline
\end{tabular}

FB: financial bonds, SOB: social bonds, STB: structural bonds, AB: affective commitment to broadcaster, AP: affective commitment to platform, $\mathrm{CE}$ : consumer engagement

Consumer engagement (CE) is the level of consumer participation and relationship with seller's offer or activity [12]. CE focuses on consumers and their needs, intending to provide more value than competitors by generating, disseminating, and responding to consumer needs. CE can also be used when trying to build trust and commitment in customer relationships [25]. CE also includes consumer involvement in various activities, not limited to searching, evaluating, and purchasing, or all consumer interactions with companies, but also consumer interactions with other consumers related to brands/companies [12].

\section{RESEARCH METHOD}

\subsection{Sampling}

The population is Indonesian e-commerce platform users who have used the live stream shopping feature. The criteria for respondents from this study are 18 years or older and have watched the Live online questionnaires which were distributed to ecommerce platform users who had used the live stream shopping feature in the last three months. Respondents were then asked to evaluate the level of related variables using a five-point Likert scale measured with (1) "strongly disagree" to (5) "strongly agree." All measurement items have been pre-tested, and adapted to the context of live stream shopping on an ecommerce platform. Fourteen items of measurement of relational bonds were adopted from [26]-[28], eight items measuring affective commitment were adopted from [23] [29], seven items measuring consumer engagement were adopted from [12] [30]. 


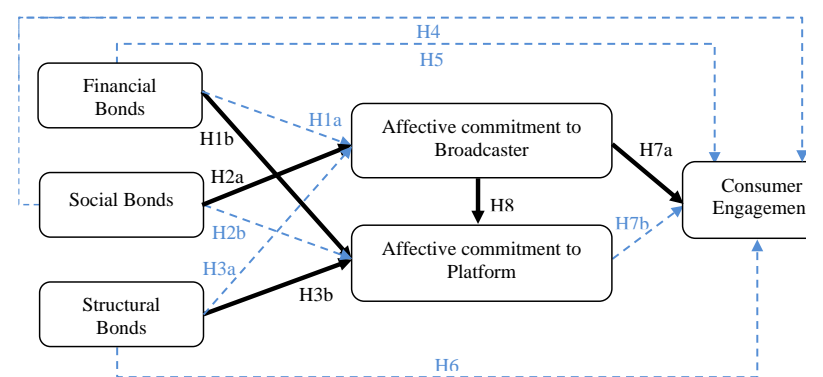

Figure 1. Result of structural model, Solid and dashed lines denote supported and unsupported hypotheses respectively
All path coefficients and hypotheses are summarized in Table 2.

SOB have a positive effect on $\mathrm{AB}$, but not on $\mathrm{AP}$. It supports $\mathrm{H} 2 \mathrm{a}$ and rejects $\mathrm{H} 2 \mathrm{~b}$. FB and $\mathrm{STB}$ have no effect on $\mathrm{AB}$, rejecting H1a \& H3a. However, FB and STB have a positive effect on AP, supporting the hypothesis H1b \& H3b. All aspects of relational bonds (financial, social, \& structural) have no effect on CE, thus rejecting $\mathrm{H} 4, \mathrm{H} 5$, and $\mathrm{H} 6$. The test results also show that $\mathrm{AB}$ has a significant effect on $\mathrm{CE}$ and also on $\mathrm{AP}$, thus supporting $\mathrm{H} 7 \mathrm{a}$ and $\mathrm{H} 8$. Meanwhile, $\mathrm{AB}$ has no effect on $\mathrm{CE}$, rejecting $\mathrm{H} 7 \mathrm{~b}$. The results of the

Table 3. Result of Mediation Analysis

\begin{tabular}{|c|c|c|c|c|c|c|c|}
\hline \multicolumn{4}{|l|}{ Total effect } & \multicolumn{4}{|l|}{ Indirect effect } \\
\hline Path & $\begin{array}{l}\text { Loading } \\
\text { factor }\end{array}$ & $\mathrm{p}$ value & & Path & $\begin{array}{l}\text { Loading } \\
\text { factor }\end{array}$ & $\mathrm{p}$ value & Result \\
\hline \multirow[t]{2}{*}{$\mathrm{FB} \rightarrow \mathrm{CE}$} & .121 & .547 & $\mathrm{H} 9 \mathrm{a}$ & $\mathrm{FB} \rightarrow \mathrm{AB} \rightarrow \mathrm{CE}$ & .049 & .749 & Not supported \\
\hline & & & $\mathrm{H} 10 \mathrm{a}$ & $\mathrm{FB} \rightarrow \mathrm{AP} \rightarrow \mathrm{CE}$ & .068 & .198 & Not supported \\
\hline \multirow[t]{2}{*}{$\mathrm{SOB} \rightarrow \mathrm{CE}$} & .676 & .001 & $\mathrm{H} 9 \mathrm{~b}$ & $\mathrm{SOB} \rightarrow \mathrm{AP} \rightarrow \mathrm{CE}$ & .929 & .011 & Supported \\
\hline & & & $\mathrm{H} 10 \mathrm{~b}$ & $\mathrm{SOB} \rightarrow \mathrm{AP} \rightarrow \mathrm{CE}$ & -.061 & .277 & Not supported \\
\hline \multirow[t]{2}{*}{$\mathrm{STB} \rightarrow \mathrm{CE}$} & .055 & .586 & $\mathrm{H} 9 \mathrm{c}$ & $\mathrm{STB} \rightarrow \mathrm{AP} \rightarrow \mathrm{CE}$ & -.123 & .646 & Not supported \\
\hline & & & $\mathrm{H} 10 \mathrm{c}$ & $\mathrm{STB} \rightarrow \mathrm{AP} \rightarrow \mathrm{CE}$ & .140 & .250 & Not supported \\
\hline
\end{tabular}

FB: financial bonds, SOB: social bonds, STB: structural bonds, AB: affective commitment to broadcaster, AP: affective commitment to platform, $\mathrm{CE}$ : consumer engagement

\section{RESULT \& ANALYSIS}

\subsection{Measurement Model}

By calculating the loading factor, composite reliability (CR) and average variance extracted (AVE) values, the measurement model is estimated. 0.5 was chosen as the threshold value that determines the validity of the item [31] [32], and there were 4 items that were deleted. In addition, only with CR alone, the researcher can conclude that the convergent validity of the construct is sufficient, even though the AVE is less than 0.5 which is the cause of error [33]. Because the $\mathrm{CR}$ value of the two variables is above 0.7 , the internal reliability of the measurement can be accepted. All assessment related to the measurement model are presented in Table 1.

\subsection{Structural Model \& Hypotheses Testing}

The results of the structural model analysis are described in Figure 1. From the model, it can be seen that in the dependent variable, the coefficient of determination (R2) is 0.659 for affective commitment to broadcasters, 0.698 for affective commitment to platform and 0.906 for consumer engagement. For simplicity, we dashed insignificant paths in the figure. mediation hypothesis test show that from the two aspects of affective commitment, only $\mathrm{AB}$ has a mediating role. It mediates only in the relationship of SOB to CE. These results support hypothesis $\mathrm{H} 9 \mathrm{~b}$, and reject hypotheses $\mathrm{H} 9 \mathrm{a}, \mathrm{H} 9 \mathrm{~b}, \mathrm{H} 10 \mathrm{a}, \mathrm{H} 11 \mathrm{a}$, and H11b

\section{DISCUSSION}

This research studies the phenomenon of live stream shopping on Indonesian e-commerce platforms as one of the activities that can improve consumers' online shopping experience. This research was conducted to expand the scope of previous research [6] by examining the effect of relational bonds on consumer engagement on live stream shopping activities on the Indonesian e-commerce platform. We found that SOB have an indirect effect on CE through affective AB. Meanwhile, FB \& STB only affect affective AP but have no effect on $\mathrm{CE}$.

It is found that $\mathrm{AB}$ is influenced by $\mathrm{SOB}$. This is in line with research [6]. [34] found that SOB have a positive effect on affective commitment. FB and STB were found to have no effect on $\mathrm{AB}$, contradicts [6]. Commitment to salesperson is only influenced by interpersonally specific aspects of the seller [35]. In live stream shopping, FB is not one of them. STB can increase consumer trust [36], [37], including live stream shopping, [6]. Another study found that 
consumer trust can increase affective commitment to the seller [35] [38]. It is possible that STB have indirect influence on the $\mathrm{AB}$ mediated by trust.

$\mathrm{AP}$ is influenced by FB and STB, in line with [6] [39] [40]. SOB have no effect on AB, contradicting previous research [6]. It is possible that the motivation of consumers to visit the e-commerce platform is to find the product you want to buy, and determine which seller to choose [41]. Socializing is not included in this motivation, thus is not associated with the platform. Consumer engagement is not directly affected by relational bonds, whether FB, SOB, \& STB. FB does not directly affectE, in line with research [6] [42]. This may be because most of the goods sold are experience goods, and are hard to judge just by their price [6] SOB \& STB do not have a direct influence on CE, in line with previous studies [43], which found that personalization and responsiveness were not directly related to consumer engagement. In live stream shopping, SOB are closely related to personalization, and STB are also closely related to responsiveness, [27] [28] [43] [44] [45]. So, it can be concluded that SOB and STB do not directly influence CE in live stream shopping.

$\mathrm{CE}$ is influenced by $\mathrm{AB}$, in line with [6], [46]. Meanwhile, is not influenced by AP, contradicts [6] [39] [40]. In the context of a live stream, the level of consumer relationship with the platform cannot lead to the consumer's desire to interact and participate in platform activities. It shows that consumer engagement is more social and interpersonal in live stream shopping on e-commerce platforms. Affective commitment to broadcaster has a significant positive effect on affective commitment to the platform, consistent with research [35] [47].

Almost all of H9 hypotheses are rejected, except for $\mathrm{H} 9 \mathrm{~b}$. These results are in line with research [6]. Meanwhile, AB does not mediate between FB \& STB on CE. Perhaps the commitment to the salesperson will only be influenced by interpersonally specific aspects [35], and financial bonds are not included in the relationship. In addition, the possibility of affective commitment to broadcaster can only be influenced by structural bonds through indirect relationships such as consumer trust. [35] [36] [37] [38]. The H10 mediation hypothesis test result showed that $\mathrm{H} 10 \mathrm{a}, \mathrm{H} 10 \mathrm{~b}$, and $\mathrm{H} 10 \mathrm{c}$ were rejected, contradicting [6]. It can happen because AP does not have a significant positive effect on $\mathrm{CE}$. It causes the effects of relational bonds not to be transmitted to $\mathrm{CE}$.

\section{CONCLUSION}

This study examines the effect of relational bonds on consumer engagement via affective commitment in Indonesian e-commerce live stream shopping. Using 266 valid online survey responses, the study found that SOB indirectly affects $\mathrm{CE}$ through AB. Meanwhile, FB \& STB only affect AP but does not affect CE. The results of this study provide great insight for ecommerce operators, especially in the COVID-19 pandemic era where online shopping is on the high.

\section{LIMITATION \& FUTURE RESEARCH}

As a relatively new phenomenon in the Indonesian e-commerce environment, it is necessary to conduct further research related to live stream shopping. Future research is suggested to use experimental or longitudinal forms to get a complete picture of the existing phenomena. This study generalizes ecommerce platforms but has not seen the differences on each platform specifically. [9] argues that consumers' intention to visit a commerce site depends on the features offered. Thus, it is recommended that further research be conducted to study further the role of feature moderation in live stream shopping

\section{REFERENCES}

[1] J. Mander et al., Connecting the Dots 2021, 2020.

[2] S. Perez, COVID-19 pandemic accelerated shift to e-commerce by 5 years, new report says , TechCrunch. 2020.

[3] A. Lidwina, Penggunaan E-Commerce Indonesia Tertinggi di Dunia, Databooks, 2021. https://databoks.katadata.co.id/datapublish/2020/ 02/26/10-media-sosial-yang-paling-seringdigunakan-di-indonesia (accessed Feb. 11, 2021).

[4] Z. Hilvert-Bruce, J. T. Neill, M. Sjöblom, and J. Hamari, Social motivations of live-streaming viewer engagement on Twitch, Computers in Human Behavior, vol. 84, pp. 58-67, 2018, DOI: 10.1016/j.chb.2018.02.013.

[5] M. Ham and S. W. Lee, Factors influencing viewing behavior in live streaming: An interviewbased survey of music fans, Multimodal Technologies and Interaction, vol. 4, no. 3, pp. 115, 2020, DOI: 10.3390/mti4030050.

[6] M. Hu and S. S. Chaudhry, Enhancing consumer engagement in e-commerce live streaming via relational bonds, Internet Research, vol. 30, no. 3, 
pp. 1019-1041, 2020, DOI: 10.1108/INTR-032019-0082.

[7] C. Y. Li and Y. C. Ku, The power of a thumbs-up: Will e-commerce switch to social commerce?, Information and Management, vol. 55, no. 3, pp. 340-357, 2018, DOI: 10.1016/j.im.2017.09.001.

[8] J. Shen, Social comparison, social presence, and enjoyment in the acceptance of social shopping websites, Journal of Electronic Commerce Research, vol. 13, no. 3, pp. 198-212, 2012.

[9] Z. Huang and M. Benyoucef, User preferences of social features on social commerce websites: An empirical study, Technological Forecasting and Social Change, vol. 95, pp. 57-72, 2015, DOI: 10.1016/j.techfore.2014.03.005.

[10] X. Xu, J. H. Wu, and Q. Li, What drives consumer shopping behavior in live streaming commerce?, Journal of Electronic Commerce Research, vol. 21, no. 3, pp. 144-167, 2020.

[11] M. Hu, M. Zhang, and Y. Wang, Why do audiences choose to keep watching on live video streaming platforms? An explanation of dual identification framework, Computers in Human Behavior, vol. 75, pp. 594-606, 2017, DOI: 10.1016/j.chb.2017.06.006.

[12] A. Wongkitrungrueng and N. Assarut, The role of live streaming in building consumer trust and engagement with social commerce sellers, Journal of Business Research, vol. 117, no. September 2018, pp. 543-556, 2020, DOI: 10.1016/j.jbusres.2018.08.032.

[13] M. Sjöblom and J. Hamari, Why do people watch others play video games? An empirical study on the motivations of Twitch users, Computers in Human Behavior, vol. 75, pp. 985-996, 2017, DOI: 10.1016/j.chb.2016.10.019.

[14] A. Mehrabian and J. A. Russell, An approach to environmental psychology. Cambridge, MA, US: The MIT Press, 1974.

[15] J. Jacoby, Stimulus-organism-response reconsidered: An evolutionary step in modeling (consumer) behavior, Journal of Consumer Psychology, vol. 12, no. 1, pp. 51-57, 2002, DOI: 10.1207/153276602753338081.

[16] R. J. Donovan, J. R. Rossiter, G. Marcoolyn, and A. Nesdale, Store atmosphere and purchasing behavior, Journal of Retailing, vol. 70, no. 3, pp.
283-294, 1994, DOI: $10.1016 / 0022-$ 4359(94)90037-X.

[17] R. Donovan and J. Rossiter, Store atmosphere: an environmental psychology approach, Journal of retailing, vol. 58, no. 1, pp. 34-57, 1982.

[18] S. A. Eroglu, K. A. Machleit, and L. M. Davis, Atmospheric qualities of online retailing, Journal of Business Research, vol. 54, no. 2, pp. 177-184, 2001, DOI: 10.1016/s0148-2963(99)00087-9.

[19] S. Menon and B. Kahn, Cross-category effects of induced arousal and pleasure on the Internet shopping experience, Journal of Retailing, vol. 78 , no. 1, pp. 31-40, 2002, DOI: 10.1016/S00224359(01)00064-1.

[20] S. Prashar, T. Sai Vijay, and C. Parsad, Effects of Online Shopping Values and Website Cues on Purchase Behaviour: A Study Using S-O-R Framework, Vikalpa, vol. 42, no. 1, pp. 1-18, 2017, DOI: $10.1177 / 0256090916686681$.

[21] L. L. Berry, Relationship Marketing of Services: Growing Interest, Emerging Perspectives, Journal of the Academy of Marketing Science, vol. 23, no. 4, pp. 236-245, 1995, DOI: 10.4135/9781452231310.n6.

[22] A. Gustafsson, M. D. Johnson, I. Roos, A. Gustafsson, M. D. Johnson, and I. Roos, The Effects of Customer Satisfaction, Relationship Commitment Dimensions, and Triggers on Customer Retention Published by: American Marketing Association Stable URL : http://www.jstor.org/stable/30166563

REFERENCES Linked references are available on JS, Journal of Marketing \, vol. 69, pp. 210$218,2005$.

[23] H. Evanschitzky, G. R. Iyer, H. Plassmann, J. Niessing, and H. Meffert, The relative strength of affective commitment in securing loyalty in service relationships, Journal of Business Research, vol. 59, no. 12, pp. 1207-1213, 2006, DOI: 10.1016/j.jbusres.2006.08.005.

[24] S. M. Fazal-e-Hasan, I. N. Lings, G. Mortimer, and L. Neale, How Gratitude Influences Customer Word-Of-Mouth Intentions and Involvement: The Mediating Role of Affective Commitment, Journal of Marketing Theory and Practice, vol. 25, no. 2, pp. 200-211, 2017, DOI: 10.1080/10696679.2016.1270769.

[25] C. M. Sashi, Customer engagement, buyer-seller relationships, and social media, Management 
Decision, vol. 50, no. 2, pp. 253-272, 2012, DOI: $10.1108 / 00251741211203551$.

[26] R. Gu, C. District, L. Oh, K. Wang, and H. District, Developing User Loyalty for Social Networking Sites: a, Journal of Electronic Commerce Research, vol. 17, no. 1, pp. 1-21, 2016.

[27] Y. C. Hsieh, H. C. Chiu, and M. Y. Chiang, Maintaining a committed online customer: A study across search-experience-credence products, Journal of Retailing, vol. 81, no. 1, pp. 75-82, 2005, DOI: 10.1016/j.jretai.2005.01.006.

[28] H. C. Chiu, Y. C. Hsieh, Y. C. Li, and M. Lee, Relationship marketing and consumer switching behavior, Journal of Business Research, vol. 58, no. 12 , pp. 1681-1689, 2005, DOI: 10.1016/j.jbusres.2004.11.005.

[29] J. L. Walker, Harrison, The Measurement of Word-of-Mouth Communication and an Investigation of Service Quality and Customer Commitment as Potential Antecedents, Journal of Service Research, vol. 4, no. 1, pp. 60-75, 2001.

[30] J. W. Lane, C. S. Lin, T. H. Tsai, and S. Renganathan, Computer configurations of supervisory units, Instrument Engineers Handbook, Fourth Edition: Process Control and Optimization, vol. 2, no. 1995, pp. 15-25, 2005.

[31] J. F. Hair, W. C. Black, B. j Babin, and R. Anderson, Multivariate Data Analysis, 7th ed. Essex: Pearsons Education Limited, 2014.

[32] N. K. Malhotra and S. Dash, Marketing Research An Applied Orientation, 7th ed. Delhi: Pearsons, 2016.

[33] C. Fornell and D. F. Larcker, Fornell, C. and Larcker, D.F. (1981), Evaluating structural equation models with unobservable variables and.pdf, Journal of Marketing Research, vol. XVIII, no. February, pp. 39-50, 1981.

[34] B. Cater and V. Zabkar, Antecedents and consequences of commitment in marketing research services: The client's perspective, Industrial Marketing Management, vol. 38, no. 7, pp. 785-797, Oct. 2009, DOI: 10.1016/j.indmarman.2007.10.004.

[35] A. Wong and A. Sohal, An examination of the relationship between trust, commitment and relationship quality, International Journal of Retail \& Distribution Management, vol. 30, no. 1, pp. 34-50, Jan. 2002, DOI: $10.1108 / 09590550210415248$.

[36] C. M. Rodríguez and D. T. Wilson, Relationship Bonding and Trust as a Foundation for Commitment in U.S.-Mexican Strategic Alliances: A Structural Equation Modeling Approach, 2002. [Online]. Available: http://www.jstor.orgURL:http://www.jstor.org/st able/

[37] N. P. Lin, J. C. M. Weng, and Y. C. Hsieh, Relational bonds and customer's trust and commitment - A study on the moderating effects of web site usage, Service Industries Journal, vol. 23, no. 3, pp. 103-124, 2003, DOI: $10.1080 / 714005111$.

[38] S. Twing-Kwong, L. G. Albaum, and L. Fullgrabe, Trust in customer-salesperson relationship in China's retail sector, International Journal of Retail and Distribution Management, vol. 41, no. 3, pp. 226-248, Mar. 2013, DOI: $10.1108 / 09590551311306264$.

[39] A. Rohm, V. D. Kaltcheva, and G. R. Milne, A mixed-method approach to examining brandconsumer interactions driven by social media, Journal of Research in Interactive Marketing, vol. 7, no. 4, pp. 295-311, 2013, DOI: 10.1108/JRIM01-2013-0009.

[40] J. van Doorn et al., Customer engagement behavior: Theoretical foundations and research directions, Journal of Service Research, vol. 13, no. 3, pp. 253-266, 2010, DOI: $10.1177 / 1094670510375599$.

[41] S. S. Manvi and P. Venkataram, An intelligent product-information presentation in E-commerce, Electronic Commerce Research and Applications, vol. 4, no. 3, pp. 220-239, 2005, DOI: 10.1016/j.elerap.2005.01.001.

[42] M. Zhou, J. Huang, K. Wu, X. Huang, N. Kong, and K. S. Campy, Characterizing Chinese consumers' intention to use live e-commerce shopping, Technology in Society, vol. 67, Nov. 2021, DOI: 10.1016/j.techsoc.2021.101767.

[43] J. Xue, X. Liang, T. Xie, and H. Wang, See now, act now: How to interact with customers to enhance social commerce engagement?, Information and Management, vol. 57, no. 6, Sep. 2020, DOI: 10.1016/j.im.2020.103324.

[44] G. Wu, Conceptualizing and measuring the perceived interactivity of websites, Journal of 
Current Issues and Research in Advertising, vol. 28, no. 1, pp. 87-104, 2006, DOI: 10.1080/10641734.2006.10505193.

[45] N. Kumar and I. Benbasat, The Influence of Recommendations and Consumer Reviews on Evaluations of Websites, vol. 17, no. 4, pp. 425439, 2006, DOI: 10.1287/isre.1060.0107.

[46] L. Guo, X. Hu, J. Lu, and L. Ma, Effects of customer trust on engagement in live streaming commerce: mediating role of swift guanxi, Internet Research, vol. 31, no. 5, pp. 1718-1744, Nov. 2021, DOI: 10.1108/INTR-02-2020-0078.
[47] B. D. Foster and J. W. Cadogan, Relationship selling and customer loyalty: an empirical investigation, Marketing Intelligence \& Planning, vol. 18, no. 4, pp. 185-199, Aug. 2000, DOI: 10.1108/02634500010333316. 